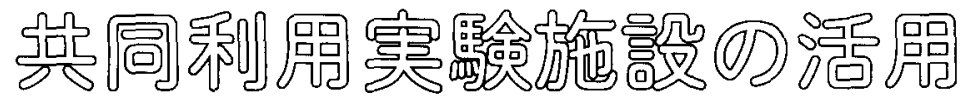

\section{9 高エネルギー物理学研究所・放射光実験施設}

\section{太田俊 明}

\section{1 はじめに}

つくば学園都市最北端の高エネルギー物理学研究所に 我が国最初の放射光 X 線が利用できる実験施設（通称

フォトン・ファクトリー) が建設されたのは 1982 年 である.それ以来 15 年近くこの放射光実験施設は全国 の共同利用施設として多くのユーザーによって活発に利 用されてきた．現在，登録利用者数は 2,000 人を越え， 実験課題数は年 350 件を越えている，放射光は紫外線か らX線にまで及ぶ強力な光であり，これを用いた研究 は物理, 化学, 生物から工学, 宸学, 医学などの様々な 応用分野に広がっている.今回の主題である電気化学あ 放射光の利用によって大きな発展が期待される分野であ る.これに関しては最近, 近藤, 魚崎による 優れた総説 ${ }^{11}$ があるのでそれを参照されたい．

フォトン・ファクトリーにおける実験対象 の大半は固体 (バルク, 表面) であり,これ に気体の原子, 分子の研究が続く。溶液（液 体）の研究は最も少ないが，世界的な趨勢上 して次第に注目されはじめ，フォトン・ファ クトリーでも近年活発になりつつあるように 思われる．筆者は電気化学を専門としていな いが, フォトン・ファクトリー建設時はスタッ フとして, 現在は大学でユーザーとして放射 光科学を業とする者として，フォトン・ファ クトリーにおける電気化学・溶液化学に関連 したいくつかの研究例を挙げ，放射光がよ゙の ように利用されているかを紹介する.

\section{2 フォトン・ファクトリー施設の概要}

フォトン・ファクトリーは $2.5 \mathrm{GeV} の$ 電 子（陽電子）エネルギー蓄皘リングからでる 放射光を利用する実験施設であり，Fig.1 に示すように 16 本の偏向磁石と 6 本の㨂入 光源(アンジュレーター, マルチポールウィ 東京大学理学部化学教室 (T113 東京都文京区本郷 7-3-1)
グラー）からの放射光をとりだして, 合計 61 の実験ス テーションに放射光を供給し，様々な実験が行われてい る. 電気化学, 溶液化学に関係した実験は専ら硬X 線 を用いたXAFS, X 線回折, 散乱実験が主と思われる. これらの主なものをTable 1 に挙げた.

\section{3 放射光を用いた溶液化学の実験}

\subsection{XAFS}

$\mathrm{X}$ 線吸収分光 (XAFS) 法は物質を構成する原子の 周りの局所的な原子構造や電子状態について情報を得る 有効な手法であり, 溶液化学です幅広く使われている. 特に, X 線吸収端近傍の微細構造 (XANES) からは,

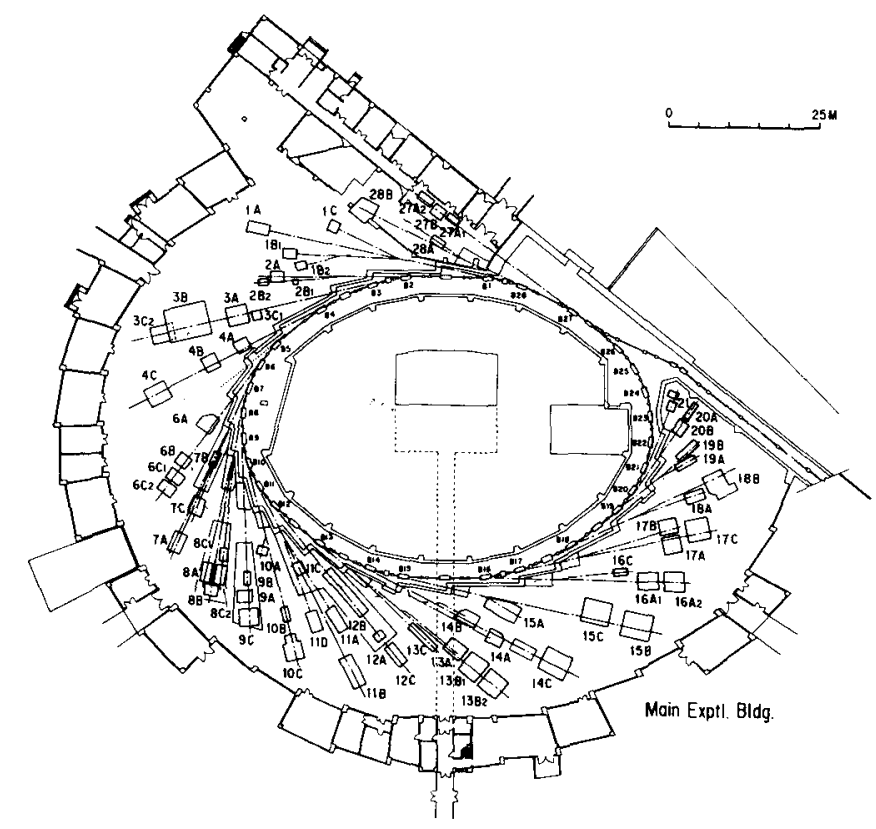

Fig. 1 Plan view of the Photon Factory Experimental Hall. 
そのピークシフトか ら特定原子の原子価 の変化がわかり,ピー 強度の変化は空状 態の空き具合の尺度 であることから，電 荷移動の程度を調心 ることができる。

方, 吸収端から $50 \mathrm{eV}$ より上, $1000 \mathrm{eV}$ 程度 までの幅広いエネル ギー領域の吸収の微 細構造 (EXAFS) 加 らは吸収原子の周り の局所構造を知るこ とができる。特に，

長距離秩序を持たな い系に対しても適用 できることから溶液 化学には有効である。 XAFS は基本的には 吸収分光法であるが， 良く用いられている 方法として透過法以 外に栄光 X 線収量法がある。これは試料中に微量に含 まれる金属のXAFS 測定に特に有効である。いずれも， 数 $10 \mathrm{~cm}$ から, $1 \mathrm{~m}$ までの $\mathrm{X}$ 線のパスを含む自由空間 によ゙のような試料とその処理装置を取り付けて測定する かが実験者の腕の見せ所である.

3.1 .1 炭素電極に担持した $\mathrm{Pt}$ 微粒子の電極電位によ る構造変化 吉武ら ${ }^{2)}$ は，イオン交換法之水素還元 で Pt 微粒子を炭素に分散させ, PTFE を成形材として ディスク状にしたあのを試料として，Fig. 2 に示す in situ XAFS 測定装置で，透過法によって $\mathrm{PtL}_{3}$-XAFS の測定を行っている. $\mathrm{PtL}_{3}$ 吸収端ピーク強度は $\mathrm{d}$ 電子 状態の空き具合 $\mathrm{f}_{\mathrm{d}}$ に比例しているが，電位を变えて $\mathrm{f}_{\mathrm{d}}$ の変化を調べると Fig. 3 に示すようにヒステリシスを 持つことが分かる。一方，EXAFSのフーリエ変換ス ペクトルはFig. 4 に示すように電位によって Pt-Pt 散 乱による振幅が変化する。ここは $\mathrm{Pt}$ の配位数が $\mathrm{Pt}$ 微 粒子の形状によって変化したことに対応する。このよう な電極電位による $\mathrm{Pt}$ 微粒子の構造変化, $\mathrm{d}$ 電子状態密 度之電位の関係を模式的に Fig. 5 に示した. In situ電 極反応で問題になるのが，電極からの気体発生によるス ペクトルの擾乱である．彼らは試料の溶液に接していな い部分を真空排気することによってこの問題を解決して いる ${ }^{3)}$.

\subsubsection{UPD 吸着 $\mathrm{Cu}$ の吸着構造の解析 金, 白}

金単結晶電極表

面上にUPD 吸 着した金属原子 はあたかも超高 真空下で清浄表 面に吸着したよ うな構造をとる ことが知られて いる.このよう な吸着原子の XAFSによる 研究は Abruna (CHESS) 弓 ${ }^{4)}$ によって精力的 に調べられてい る.しかし，ス ペクトルの質は 必ずしも高いと はいえず，より信頼の高いスペクトル測定が必要と思わ れる. また，面の違いや陰イオンの影響など調べること はまだ多く残されている，最近，我々 ${ }^{5)}$ 屯同様の実験を 収束ビームが得られる BL-12 Cで始めた，テフロン製 の小型電気化学セルを作り, $10 \mathrm{~mm} \phi$ の $\mathrm{Pt}$ 単結晶上に UPD 吸着させた $\mathrm{Cu}$ つ XAFS を全反射条件で蛍光 X 


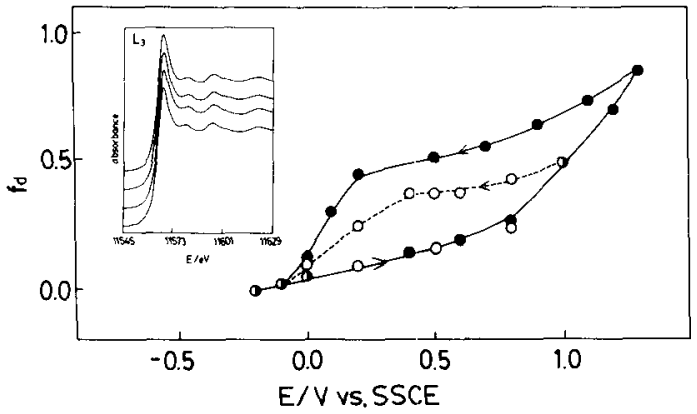

Fig. 3 Degree of Pt 5 d-electron vacancy, $f_{d}$ vs. potential for $0.26 \mathrm{M} \mathrm{H}_{2} \mathrm{SO}_{4}$ solution. Inserted figure is $\mathrm{Pt}_{3}$ edge spectra at $-0.2,0.0,0.5$ and 1.0 $\mathrm{V}$ vs. SSCE.

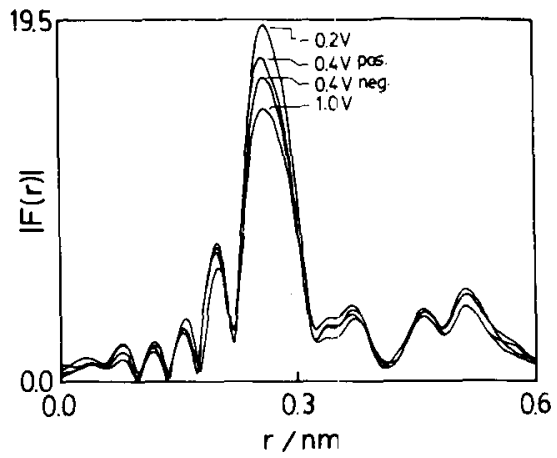

Fig. 4 Fourier transformed spectra of $\mathrm{Pt} \mathrm{L}_{3}-$ EXAFS in $0.26 \mathrm{M} \mathrm{H}_{2} \mathrm{SO}_{4}$ solution.

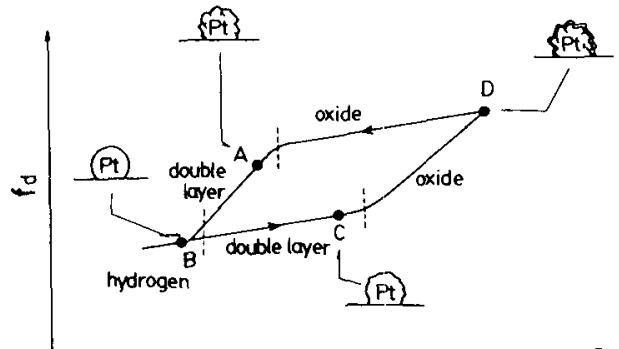

electrode potential

Fig. 5 Schematic model of the Pt particle structures on an $f_{d}$ voltammogram in relation to the electrode potential. The hydrogen, doublelayer and oxide regions are based on cyclic voltammetry. The disorder of the particle lattice is in the order $\mathrm{D}>\mathrm{A}>\mathrm{C}>\mathrm{B}$.

線収量法で測定している. Fig. 6にはSSCE 基準の0.0V における Cu/Pt (111) の Cu K-EXAFS とそのフーリ エ変換スペクトルを $\mathrm{s}$-偏光, $\mathrm{p}$-偏光に対して示した. $\mathrm{s}-$
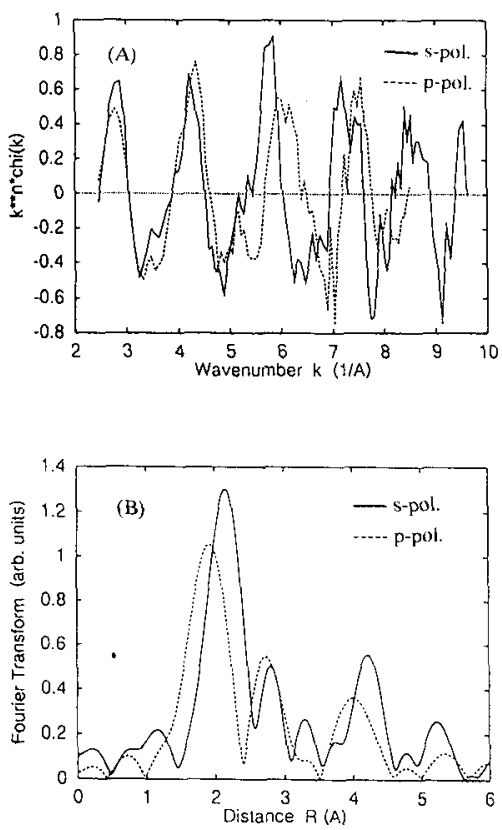

Fig. 6 (a) Cu K-EXAFS spectra of UPD deposited $\mathrm{Cu}$ on $\mathrm{Pt}(111)$. (b) Fourier transformed spectra of (a). Solid line: s-polarized light, dashed line: $p$-polarized light.

偏光では $\mathrm{Cu}-\mathrm{Cu}$ が, p-偏光では $\mathrm{Cu}-\mathrm{Pt}, \mathrm{Cu}-\mathrm{O}$ による散 乱が観測されている.このスペクトルの解析から $\mathrm{Cu}$ は $\mathrm{Pt}$ (111) 面の hollow siteに吸着していることが明らか になった，現在解析中であるが，偏光特性の利用によっ て電極表面のより詳細な構造が解明できると思う。

3.1 .3 水溶液表面の構造 水溶液の表面はバル クと異なる濃度を持ち，溶媒和構造も異なっていると考 えられる。これを調べるために渡辺ら ${ }^{6)}$ はFig.7 すような実験装置を開発して BL-7 C で XAFS 测定を 行っている，まず，水溶液の入った平たい容器を $\mathrm{He}$ 雲 囲気中に入れ，X線を全反射条件で入射する，BL-7 C は収束光学系によって水平より下向きにX 線が入射す るので本実験には望ましい，全反射条件ではX 線は溶

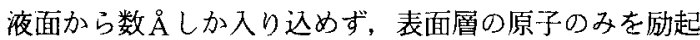
する，水溶液表面に存在する原子の XAFS スペクトル は溶液の $1 \mathrm{~cm}$ 上においた平板電極にバイアス電圧をか けて全電子収量を測定する，いわゆる転換電子収量法を 用いて得ている. Fig. 8 に $0.1 \mathrm{mM}$ スデリルトリメ チルアンモニウム具化物（STAB）水溶液のXAFS ス ペクトルを $\mathrm{I}_{0}, \mathrm{I}$ と共に示す。この解析加ら表面活性な 陽イオンによって臭素イオンが表面に析出された構造が 明らかになった。

3.1 .4 溶液反心のダイナミックス これまでの XAFS 測定は土ネルギー掃引によって行うもので，速 


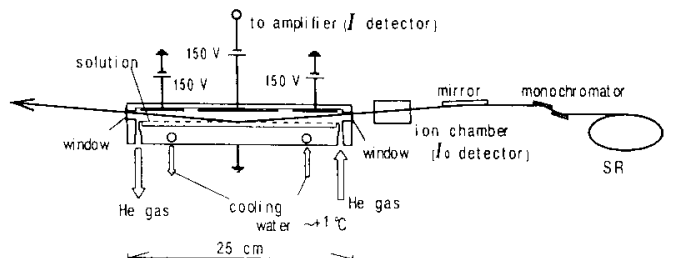

Fig. 7 XAFS experimental setup with the total reflection conversion electron yield method.

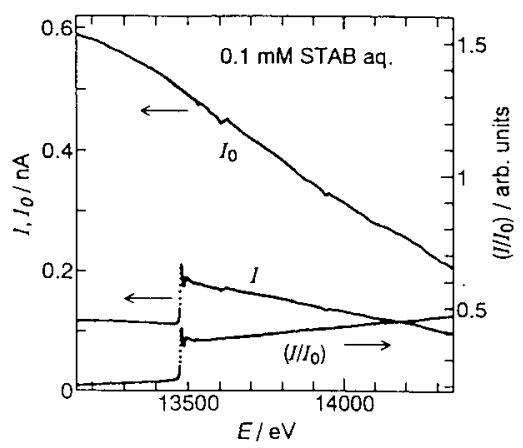

Fig. $8 \mathrm{Br}$ K-EXAFS of $0.1 \mathrm{mM}$ STAB (stearyltrimethyl ammonium bromide) aqueous solution near the liquid surface. $I_{0}$ and I were measured by the ion chamber and $\mathrm{He}^{+}$ion yield, respectively.

くとも10分はかかる.これに対して, エネルギー分散 型のXAFS ではFig. 9 に示すように，平行な放射光を 湾曲結晶を用いて異なる波長の光に分け，これを試料に 集め, 透過した後分散したものを位固敏感検出器で同時 に測定するものである77.したがって，ミリ秒のスケー ルでスペクトルを得ることが可能になり，特に，ストッ プトフローと組み合わせると, 溶液反忘における構造変 化の研究にも適用できる，西郷ら ${ }^{8)}$ はこの方法を用いて $\mathrm{Fe}_{3}\left(\mathrm{NO}_{3}\right)_{3}$ 水溶液に $\mathrm{Na}_{2} \mathrm{~S}_{2} \mathrm{O}_{3}$ を加えることによって $\mathrm{Fe}^{3+}$ から $\mathrm{Fe}^{2+}$ に変化していく様子を調べている（Fig. 10 参照). しかし，フォトン・ファクトリーでは，その 後ユーザーの強い要望が無く装置も解体されているのは 残念である.フランスではこの方法は触媒反応など様々

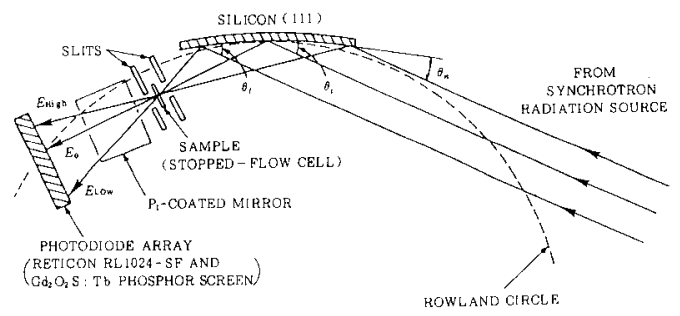

Fig. 9 Experimental geometry of the dispersive $\mathrm{XAFS}$.
な系に活用されていて，電極反応のダイナミックスの研 究例 ${ }^{9)}$ 毛報告されている。

\section{$3.2 \mathrm{X}$ 線小角散乱}

$\mathrm{X}$ 線回折は物質の原子構造を決定する方法としてフォ トン・ファクトリーの重要な研究分野である. 回折角が 数度以下の小さい角度になると，同じX 線回折であ Bragg の公式から分かるように，数 $\mathrm{nm}$ からミクロン オーダーの構造に関する情報が得られる。これは液晶, 高分子や生体物質の組織構造なよ゙には適した手法である. 特に, 高感度の検出器であるイメージングプレートが開 発されて，これらの構造のダイナミックスに関する情報 も得られるようになった。

\section{2 .1 筋収縮の分子機構筋収縮の分子機構は} Huxley の「ミオシン頭部首振り説」が提案されて以来 その検証のために，様々な手法で研究が行われているが, X 線小角散乱のビームライン BL-15 A（Fig. 11 参照） でも, 若林らによって ATP 分解中のミオシン頭部の構 造変化が調べられている ${ }^{10)}$. Fig. 12 に核酸が無い上き （A）とATP 分解中（B）での X 線散乱強度を示した。 ミオシンの分子形態を值径 $10 \AA$ の球 320 個を使って最 密充填法で表現し，散㰾強度を再現する形状を決めたも のが Fig. 12 の挿入図である.ATP 加水分解中で尾部 側の重心が約 $4 \mathrm{~nm}$ 動き分子全体が曲がるような変化を していることが分かった. ATP 分解サイクルと力学反 応が 1 対 1 に対応するとされていて, 筋収縮機構との関 連で興味深い。

3.2 .2 強誘電性液晶の微細構造液晶が薄いセ ルに挟まれたとき，層構造はシェブロン型になることが 知られているが，その層欠陌がどのような構造をとるか は分かっていない，最近，飯田らは ${ }^{11)}$ BL-4 A で開発 された X 線マイクロビーム装置に小角散乱の装置を組 み合わせて, 液晶の局所構造の研究を行っている.

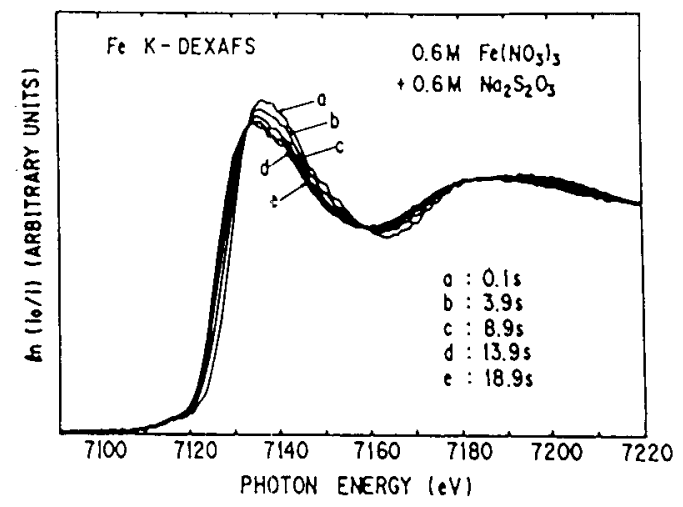

Fig. 10 Fe K-XANES spectra of $0.6 \mathrm{M} \mathrm{Fe}\left(\mathrm{NO}_{3}\right)_{3}$ aqueous solution after mixing with $0.6 \mathrm{M} \mathrm{Na} 2 \mathrm{~S}_{2} \mathrm{O}_{3}$ solution. 


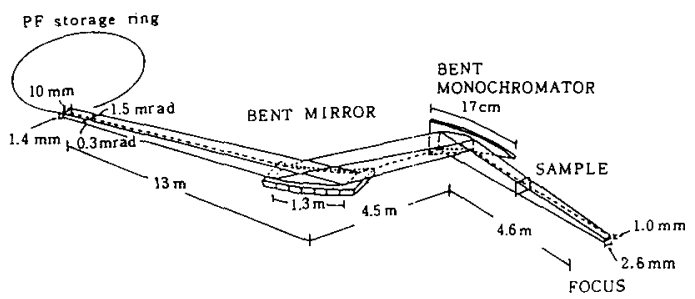

Fig. 11 X-ray optical system of BL 15-A for the small angle $\mathrm{X}$-ray scattering experiments.
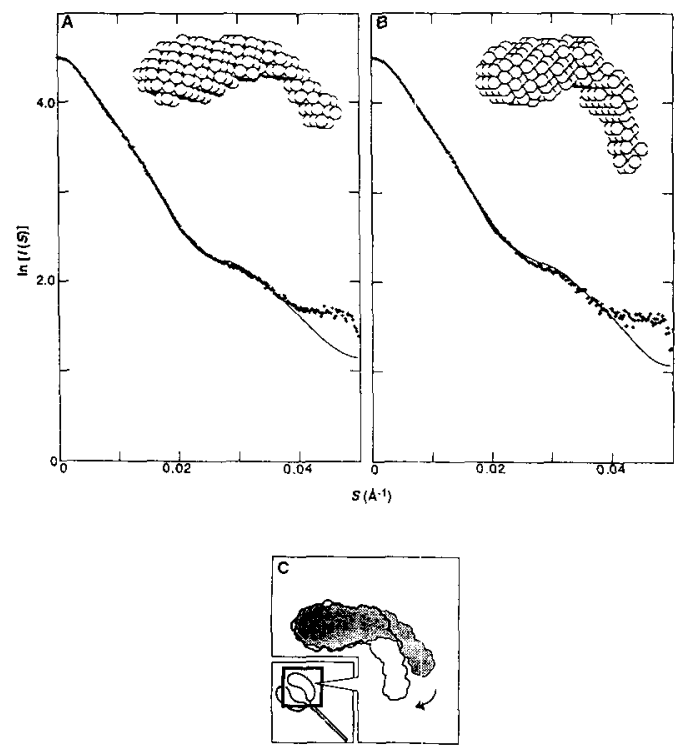

Fig. 12 Structural model of the myosin head proposed by the small angle X-ray scattering experiment. (A) myosin head without nucleotide, (B) myosin head with $\mathrm{MgATP}$, (C) Comparison of the two structural models (Hatched one is the free myosin).

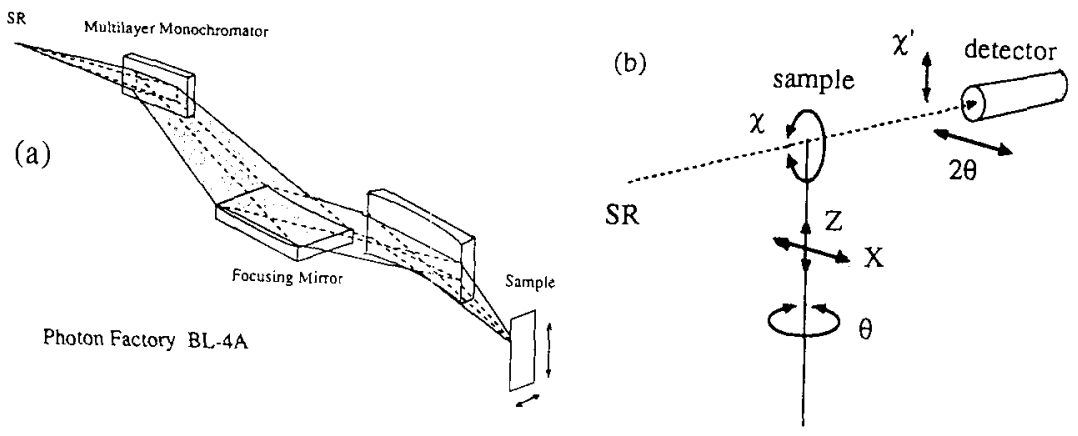

Fig. 13 (a) X-ray micro-beam optical system with the Kirkpatrick-Baez method. (b) Experimental leyout of the X-ray micro-diffraction for a liquid crystal.
Fig. 13 は実験のセットアップを示す.マイクロビーム

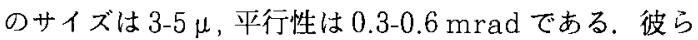
は液晶の欠陥領域で位置を少しずつ変えながら X 線回 折パターンを測定している. Fig. 14 に測定例を示す. シェブロン構造に特有のピーク $\mathrm{P}_{\mathrm{L}}, \mathrm{P}_{\mathrm{H}}$ 以外に $\theta=0$ 近 傍に新しいピークが出現する。これは図中に示したよう に，境界領域が部分的にbookshelf 構造に変化してい ることを示唆している.

\section{3 全反射 $\mathrm{X}$ 線表面回折}

表面の構造を調べようとするとき，侵入深度が大きい $\mathrm{X}$ 線は不利であるが，全反射条件で X 線を入射すれば, 侵入深度は高々数 $10 \AA$ となり，表面構造を調べる有効 な手法しなる。この表面 X 線回折法は固体表面構造に 多く用いられているが，水面上の構造や水溶液中の電極 表面の構造にも適用できる，試料を表面垂直軸の周りに 回転し（ $\theta$ 回転），これに合わせて検出器を回転 $(2 \theta$ 回 転）すると，表面二次元構造が決定できる．また，検出 器を特定の回折ピークに合わせて表面垂直方向に掃引す る方法は CTR (Crystal Truncation Rods) 法之呼 ばれ，表面深さ方向の構造や表面粗さに関する情報を得 ることができる。

松下ら ${ }^{12)}$ は Fig. 15 に示すような実験配置により， 水面上の単分子膜に全反射条件でX線を入射し， $\theta-2 \theta$ スキャンによって表面の二次元構造を調べている. Fig. 16 はシアニン水溶液上のエイコサン酸単分子膜の 表面圧を变えた実験の解析から，鉛直軸からの傾きと表 面压との関係をプロットしたものである，表面圧の上昇 にしたがって分子軸が直立していく様子が分かる。この 実験には高いX 線強度が必要とされるので BL-16 A (MPW) に抽いて行われた，その後，電極表面の吸着 原子の構造やその電位による構造変化はOcko (Brookhaven) らによって精力的に調べれられ多くの 興味有る結果が出るようになった。フフトン・ファクトリー で李最近，魚踦（北大），板谷（東北大）らが BL-16 (MPW) で電極表面の構 造研究の実験を始めている.

\section{4 実際に放射光を 利用するには}

フォトン・ファクトリー の利用実験をするには年 2 回 (11月，3月締切) の利 用研究課題申請をする必要 がある，申請書の書き方は 殆ど科研費の場合と同じで あるが，放射光が必要な理 由を明記する必要がある。 しかし, 初ぬての場合, ビー 


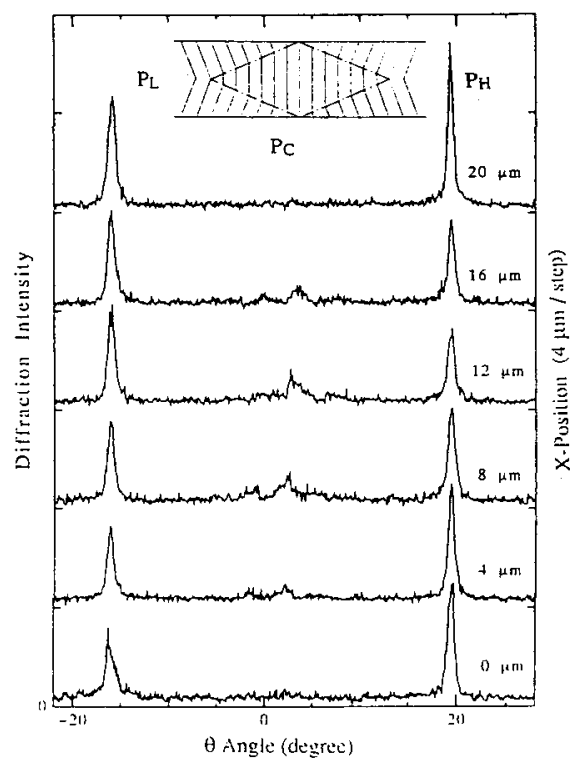

Fig. 14 Series of X-ray diffraction spectra across the broad wall in a liquid crystal. Inserted is a structural model of the layer boundary.

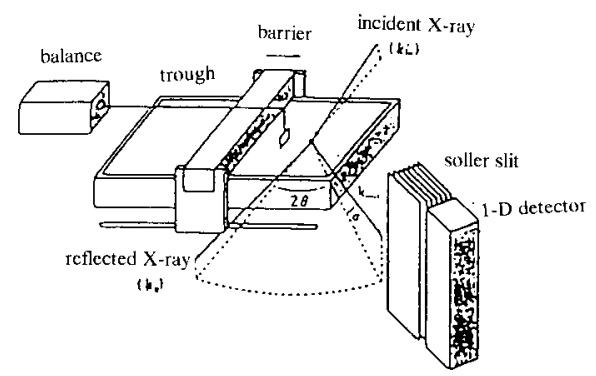

Fig. 15 Experimental setup for the surface diffraction of a LB film on a water.

\section{ムライン担当者と良く打ち合わせをし，実際に実験現場} を見て，どのような設備がそろっているか，測定装置の 周辺の状況はどうなっているか，また，光の強度はどの くらいか（ステーションによって異なる）等について予 め調べておくことが肝要である．課題が採択されると実 験期間が割り当てられ，旅費，滞在費が支給される．24 時間運転であるから，長期間に亘る実験の場合は人数を 揃え，計画を立てて行わないと体力が持たなくなる．実 験室での実験に慣れている化学研究者にとっては, 工場

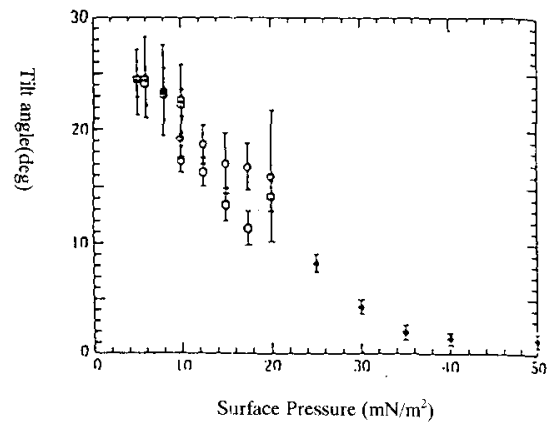

Fig. 16 Structure of eicosenoic acid on the cyanine aqueous solution. Tilt angle of the molecular axis vs. surface pressure.

のような実験ホールで限られたマシンタイムで行う実験 にはかなりバリアがあるかむしれない，しかし，実験室 では出来ない興味有る奏験がアイデア一つでいくらでも できる，放射光研究は力法論開発の時代から，興味有る 物質系を持った化学者が主役になる時代に移万うとして いる.

\section{女献}

1）近藤敏啓，魚崎浩平、表面，33，580 (1995).

2) H. Yoshitake, T. Matsuzaki, O. Yamazaki and K. Ota, J. Electroanal. Chem., 361, 229 (1993).

3) H. Yoshitake, O. Yamazaki and K. Ota, J. Electroanal. Chem., 371, 237 (1994).

4) H.S. Yee and H.D. Abruna, J. Phys. Chem., 97, 6278 (1993).

5) O. Endo, H. Hamamatsu, T. Yokoyama and T. Ohta, to be submited.

6) I. Watanabe and H. Tanida, Anal. Science, 11, 525 (1995).

7) T. Matsushita and P. Phizackerley, Jpn. J. Appl. Phys., 20, 2223 (1981).

8) S. Saigo, H. Oyanagi and T. Matsushita, $J$. de Physique C 8, 555 (1986).

9) E. Dartyge, A. Fontaine, G. Tourillon and A. Jucha, J. de Physique C 8, 607 (1986).

10) K. Wakabayashi, M. Tokunaga, I. Kohno, Y. Sugimoto, T. Hamanaka, Y. Takezawa and Y. Amemiya, Science, 258, 443 (1992).

11) A. Iida, T. Noma and H. Miyata, Jpn. J. Appl. Phys., 35, 160 (1996).

12) T. Matsushita, A. Iida, K. Takeshita, K. Saito, S. Kuroda, H. Oyanagi, M. Sugi and Y. Furuta, Jpn. J. Appl. Phys., 30, L 1674 (1991). 